\title{
Medicolegal
}

\section{Compulsory treatment of the mentally ill}

\author{
BY OUR LEGAL CORRESPONDENT
}

As was recently reported in this column (11 January, p 128), the Court of Appeal has held that a psychiatric patient was not barred by section 139 of the Mental Health Act 1983 from applying for judicial review of an application for her admission to hospital under section 3 of the 1983 Act. ${ }^{1}$ Later the patient (referred to in the later reports as "W") made a successful application to $\mathrm{Mr}$ Justice McCullough for judicial review. A similar application made at the same time by a patient designated " $L$ " was also successful."

Those decisions showed that the 1983 Act does not authorise the compulsory treatment of patients who are not detained in hospital as inpatients.

Letters of The Times have since pointed out that this leaves a serious gap in the powers of medical workers to intervene when a person suffering from schizophrenia, who might be successfully treated without admission to hospital, allows his health to decline by neglecting treatment. ${ }^{3.5}$

The attitude taken by the court in interpreting the 1983 Act is that it is a serious deprivation of liberty to be compelled to undergo treatment whether or not accompanied by temporary detention and that such a course cannot be taken without express authority from parliament by legislation.

\section{Leave of absence}

W was admitted to Banstead Hospital Surrey on the recommendation of two doctors so that she could be granted leave of absence after one night under section 17 and thereafter receive injections while on leave of absence. The doctors believed that they had the power to make such a recommendation under section 3 of the 1983 Act.

Both in the case of W (and in the case of $L$ heard at the same time) there was no questioning of the doctors' clinical judgment or good faith or qualification under the Act. The challenge was in respect of the lawfulness of the action taken. Mr Justice McCullough compared the Mental Health Acts of 1959 and 1983. The 1959 Act made no provision for treating a patient without his consent, whereas part IV of the 1983 Act specifically dealt with a patient's consent to treatment. The 1983 Act does not, however, authorise treatment of a patient without his consent unless he is detained in a hospital or had first been detained and given leave of absence under section 17 and remained liable to be detained. The effect of $\mathrm{Mr}$ Justice McCullough's decision is to declare that it is unlawful to secure the detention of a patient, or to extend his liability to detention, when the intention of the treating doctor is not to secure treatment in hospital as an inpatient but to treat as an outpatient or at some place outside the hospital.

The judge said that parliament was not presumed to have enacted legislation interfering with a subject's liberty unless that intention was made clear; so that no one was to be detained in a hospital or undergo such medical treatment without his consent, and that was applicable to a mentally disordered person as to anyone else.

A recurring phrase in section 3 is "admission for treatment." The judge held that those words could not apply to those whom it was intended to admit for a purely nominal period during which no essential treatment would be given. He added that treatment in a hospital did not mean treatment at a hospital. A distinction should be made between those whom it was appropriate to treat in a hospital as opposed to those treated otherwise; and the doctors had not regarded inpatient treatment as appropriate for W.

A comparison of section 3 of the 1983 Act with the corresponding section of the 1959 Act, section 26, confirmed the judge's view. In particular, one of the conditions for admission for treatment in the 1959 Act was: "That it is necessary in the interests of the patient's health or safety or for the protection of other persons that the patient should be so detained."

The corresponding provision in the 1983 Act reads: "That it is necessary for the health or safety of the patient or for the protection of other persons that he should receive such treatment and it cannot be provided unless he is detained under this section."

The requirement that the treatment cannot be provided unless the patient is detained is particularly important. The judge held that section 3 applied to those whose mental condition was believed to require inpatient treatment and therefore the recommendation for W's detention overnight was unlawful and it followed that she did not come within the class of persons who could be treated against their will.

\section{Clinical improvement}

The facts in the case of $\mathrm{L}$ were different. He had been detained for treatment in Banstead Hospital under section 3. The original detention was not challenged. His condition improved after treatment and he went home on leave of absence under section 17. Generally a patient on leave of absence ceases to be liable to be detained after six months unless the liability to be detained is extended under section 20. That extension is made or not made as the case may be on the basis of a report of an examining doctor. Section 20 requires the examining doctor to consider whether he is satisfied of certain conditions similar in terms to the grounds for admission in section 3 .

The doctor examined $\mathrm{L}$ before his leave of absence expired (but not at Banstead Hospital) and reported to the hospital managers that if his condition was not to deteriorate it was necessary to continue with his medicine, though not in the hospital. On that basis the authority for his detention was renewed.

The judge said that section 20 also infringed the liberty of the subject and where the word "detained" was used in the section it had to mean what it said. One of the conditions of which the reporting doctor had to be satisfied was that the patient needed treatment and that the treatment "cannot be provided unless he continues to be detained." Moreover, the reporting doctor is required by section $20(3)$ (b) to report "to the managers of the hospital where the patient is detained." The judge held that this does not mean the same as "the managers of the hospital where the 
patient is liable to be detained." If the patient is not actually detained there is no one authorised to receive the report nor can the examining doctor lawfully report.

The judge held that the similarity of language between section 3 and section 20 suggested that section 20 was also concerned with those believed to require inpatient treatment. A patient on leave of absence whom it was not necessary to recall did not require such treatment. The renewal provisions in section 20 were not intended to cover those liable to be detained but not in fact detained.

$\mathrm{L}$ was not a patient who required inpatient treatment. The report to the hospital managers was invalid because $\mathrm{L}$ was not a patient who was detained at the time of examination and report. The renewal of L's liability to detention by the managers on the basis of the doctor's report was, therefore, unlawful.

\section{References}

1 Anonymous. Actions by psychotic patients. $\mathrm{Br} \mathrm{Med} \mathcal{J}$ 1986;292:128.

2 Anonymous. Detention lawful for in-patient treatment only. The Times 1985 Dec 28:8 (cols 1-6).

3 His Honour Judge Alistair Bell. Mental health. The Times 1986 Jan 7:15 (cols 4-5).

4 Cooke JA. Mental disorder. The Times 1986 Jan 14:15 (cols 3-4).

5 Doig RJ. Mental health The Times 1986 Jan 15:15 (col 3).

\section{Epidemiology}

\section{Monthly report from the PHLS CDSC}

An outbreak of salmonellosis associated with spray dried infant milk was widely publicised early in January. Respiratory infections were prevalent in children and adults, with several reports of outbreaks of influenza $\mathrm{A}$ in institutions at the end of the month. Twelve more cases of the acquired immune deficiency syndrome (AIDS) were reported in the United Kingdom, bringing the total to 287 by 31 January.

\section{Salmonellosis}

During November and the early part of December 1985 the division of enteric pathogens at the Central Public Health Laboratory, Colindale, London, identified an increasing number of isolates of Salmonella ealing, many from infants aged under 1 . This serotype is uncommon, and the sudden increase suggested a common source outbreak. Preliminary epidemiological investigation showed an association between infection and the consumption of two formulations of a single brand of dried infant milk, and this was confirmed within 48 hours by a case-control study.

In the light of these epidemiological findings the manufacturers, Farley Health Products Limited, withdrew from the market the two implicated milks, Osterfeed and Ostermilk Complete Formula, and also two other products made in the same factory, Ostermilk Two and Complan. The organism was subsequently isolated from the dust extraction system at the factory and later from an opened packet of Osterfeed collected from a household in which infection had occurred and from two sealed packets of the same batch. Investigations are continuing to determine the source of the infection.

By January the outbreak had ended. Of 39 cases in which the date of onset of symptoms was known, 25 occurred in November, 17 in December, and only two in January; both of these last cases were contacts of children who became ill in December.

\section{Acute respiratory infections}

Clinicians will be aware of the rise in acute respiratory infections during December and January. Several pathogens were circulating in the population, notably respiratory syncytial virus, parainfluenza virus types 1 and 2, Mycoplasma pneumoniae, and Bordetella pertussis, but data from the Royal College of General Practitioners do not suggest a higher than average incidence of pneumonia, bronchitis, and upper respiratory infections for the time of year.
Both mycoplasma infections and whooping cough show a four year cycle (figure). The incidences of both increased during 1985 and are expected to increase further during 1986. The epidemiological pattern of influenza is unpredictable; there was little evidence of either influenza A or B activity throughout the autumn

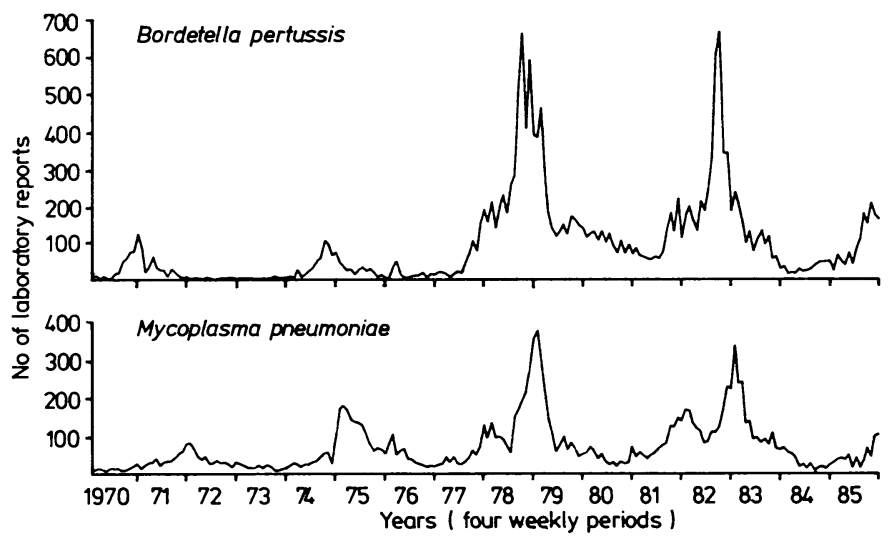

Cyclical pattern of Bordetella pertussis and Mycoplasma pneumoniae in England and Wales, 1970-85.

and early part of January, but in the last week of January several outbreaks of influenza A H3N2 in old people in institutions were reported. As this strain has been circulating in the population since 1975-6 many people are probably immune and a large outbreak seems unlikely.

\section{AIDS}

The surveillance of AIDS in the UK is based on confidential reports sent to the CDSC by clinicians and medical microbiologists, in addition to mortality data provided by the Office of Population Censuses and Surveys. By 31 January 1986, 287 patients had been reported as having AIDS, of whom $144(50 \%)$ had died. Over 16500 cases had been reported in the United States, with a similar mortality, and the estimated number world wide was over 25000 .

Of the cases in the UK, 255 (89\%) were in homosexual or bisexual 